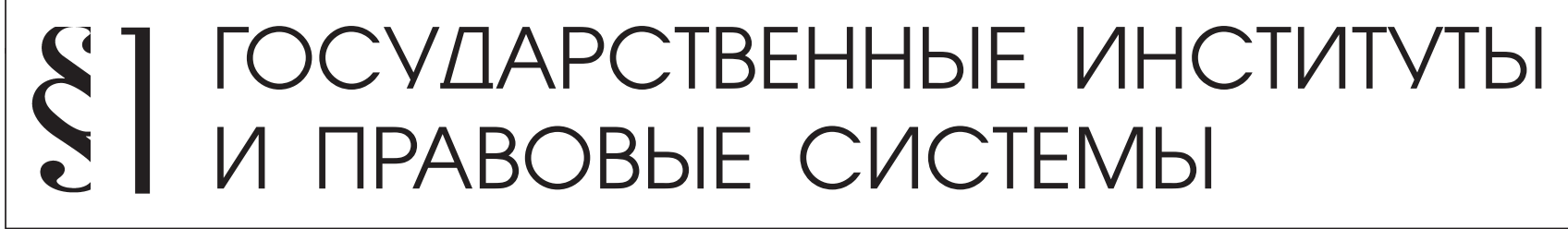

Trofimova I.N

\section{INDEXES AND OBJECTIVES OF THE SOCIO-ECONOMIC DEVELOPMENT OF THE RUSSIAN REGIONS}

\begin{abstract}
This article examines the peculiarities of the socio-economic development of the regions in Russia. The relevance of this research is justified by the growing disparity between various social classes, as well as separate territories. A special attention is given to the analysis of the correlation between the level of gross regional product (GRP) per capita and the level of average monthly income amongst region's inhabitants. These indexes are reviewed not only as important factors of current situation within the regions, but also as strategic markers of a long-term socio-economic development. The theoretical and methodological basis of the research consists of the combination of positions that argue the greater importance of internal potential of socio-economic development of the regions in comparison to the administrative and political factors. The main conclusion of the research is determination of the existing disparity within the current socioeconomic position of the regions and unfounded domination of the administrative and political approaches in setting the long-term goals for regional development. Inclusion of the indexes of the average monthly income and GRP into the longterm strategies for the socio-economic development of the regions must account not only for the administrative measures,
\end{abstract} but also for the development of internal potential of the regions, their cultural, economic, and social specificity.

Keywords: Socio-economic development, region, regional policy, average wages, gross regional product, indicators, development strategies, strategic planning, regional disparity, internal potential.

Аннотация: В статье рассматриваются особенности сочиально-экономического развития регионов России. Актуальность исследования обусловлена растущей значимостью проблемы неравенства, как между различными слоями населения, так и между отдельными территориями. Особое внимание уделяется анализу соотношения показателей уровня внутреннего регионального продукта на душу населения и уровня среднедушевых денежных доходов населения региона в месяи. Данные показатели рассматриваются не только в качестве важных факторов текущего положения регионов, но также как стратегические ориентиры долгосрочного сочиально-экономического развития. Теоретико-методологической основой исследования является совокупность положений, аргументируюших бо́льшую значимость внутреннего потенциала социально-экономического развития регионов по сравнению с административными и политическим факторами. Основным выводом исследования является выявление существенного различия в текущем сочиально-экономическом положении регионов и необоснованность доминирования административных и политических подходов при определении долгосрочных иелей регионального развития. Встраивание показателей уровня среднедушевых доходов населения и уровня ВРП в долгосрочные стратегии сочиально-экономического развития регионов должно предусматривать не только административные меры, но также развитие внутреннего потенциала регионов, учет их культурных, экономических и социальных особенностей..

Ключевые слова: Сочиально-экономическое развитие, регионы, региональная политика, доходы населения, внутренний региональный продукт, индикаторы, стратегии развития, стретегическое планирование, региональное неравенство, внутренний потенциил.

nsuring the stability of socio-economic development within the regions is one of today's strategic tasks of the government policy, which is caused by the deficiency of resources, declining quality of life and environment within the regions, growth in social disparity, underdeveloped infrastructure and other factors.

In the process of developing and implementing the programs for socio-economic development in the regions the primary focus is on the growth of production of the GRP as the foundation for improving the level and quality of life among regional population. At the same time, the programs for regional development often do not take into account as to what extent does the GRP actually affect the quality of life and ignore the objectively clear differences between the regions. The reflection of this problem can be found in a number of comparative interregional 
researches on the standard of living. Thus analysis of the correlation between the level of average wages among the regional population and the GRP within the regions of Volga Federal District allowed us to draw a conclusion on the faster growth of average wages compared to the growth in the GRP, which contributes to the piping of all created surplus value into income, and in long-term perspective results in a depressive economic situation within the region [1]. Within a number of regions we can observe the opposite trend. The lagging of the wages growth as compared to the growth in GRP leads to a decline in the level of welfare of the population [2].

The regional correlation of tempos of economic growth and the tempos of growth of welfare of the population represents a key factor of a stable socio-economic development of the regions. The average index of GRP per capita across Russia increased during the period of 2003-2012 from 229,000 to 349,000 rubles per person by 2012 prices. Overall, the correlation between different types of regions remains fairly stable. The above average GRP per capita can be seen only in the highly developed regions: in 2012 the financial centers demonstrated an increase of 1.8 times higher than average, and the raw material exporting regions - 3.1 times higher. However, the gap between these and other types of regions is slowly closing, especially after 2007 . Thus, over the period after the 2008 crisis the level of development of the Russian regions has slightly "equalized" [3]. Currently, we can observe a growing differentiation of the regions of the Russian Federation by size of the GRP per capita, which takes place on the background of general dynamics of the level of production in the country. The positive changes are mostly characteristic for the strong regions, while the economic position of the underdeveloped regions continues to degrade, which contributes to a further increase in the differentiation between the regions. These trends are especially noticeable in the conditions of the current economic crisis associated with the drop in oil prices, weakening of the ruble, and the sanctions by the United States and Western Europe.

The difference in wages among the regions is also significant. The number of regions with average monthly wages above national average is three times smaller than of those with the average monthly wages per capita that are below the national average. Among the leading regions are Moscow, oil and gas regions, and northern territories of the Far East; on the opposite side - the republics of Northern Caucasus. The external factors heightened the negative trend within the dynamics of the wages of the population. The drop in the actual wages of the population (-0.6\% in 2014 compared to 2013) is caused by the drastic devaluation of the ruble and a spike in the growth of inflation. The data for 2014 demonstrates a decrease in the actual income of the population in almost $40 \%$ of the regions, including the majority of the regions of Siberia, Ural and Northwestern, and half of the Central regions. The average wages continued to grow only within the regions of Southern, North Caucasian Federal Districts, and almost all of the Volga Region with the exception of Samara Oblast. Thus, Russian regions have significant differences by both, the GRP, and the level of average monthly income per capita.

The analysis of the correlation between the level of average income of the population and the level of GRP per capita lets us to arrange the regions according to what extent does their GRP allow them to meet their requirements for development, support the necessary level of welfare of the population, as well as contribute to the solution of national issues. First and foremost, we should indicate the differences between the Federal Districts, which can be arranged in the following way (see Table 1):

\section{Table 1}

\section{Correlation between the level of average monthly income of the population and the level of the GRP per capita} (based on the data from 2012)

Ural Federal Distric

24.3

Northwestern Federal District

18.9

Far Eastern Federal District

17.5

Siberian Federal District

14.9

Volga Federal District

13.2

Central Federal District

12.3

Southern Federal District

11.5

North Caucasian Federal District
7.8

15

Average value

Source: data from the Federal State Statistics Service 
DOI: $10.7256 / 1811-9018.2015 .10 .15672$

При цитировании этой статьи сноска на dоі обязательна

\section{Право и политика 10 (190) • 2015}

The average value of the correlation between the level of average monthly wages of the population and the level of GRP per capita throughout the country amounted to 15 in 2012. At the same time, is the Ural Federal District thanks to the "contribution" of the two autonomous districts - KhantyMansi Autonomous Okrug and Yamalo-Nenets Autonomous Okrug [4]. The higher the value of the correlation between the level of average monthly wages of the population and the level of GRP per capita, the higher the inner potential of the region for development. In this regard the Central Federal District holds a far from leading position, and even Moscow as a constituent of the federation has the value of 18 . can only take place based on the votes of the majority of the citizens living in the okrug and have the right to vote. However, majority of the okrug's population have a very negative attitude towards the idea of the merger with the Arkhangelsk Oblast.

As demonstrated on the example of the Nenets Autonomous Okrug and Arkhangelsk Oblast, there can be a significant difference in the ratio of the level of GRP per capita and the level of average monthly wages among the regions inside federal districts. The biggest gap between these indexes is recorded within the Northwestern Federal District, and the smallest - in the Southern Federal District (see Table 2).

Table 2

The difference in the ratio between the level of GRP per capita and the level of the average monthly wages by federal districts

\begin{tabular}{|l|l|l|c|}
\hline \multicolumn{1}{|c|}{ Federal districts } & \multicolumn{1}{|c|}{ Regions with the highest values } & Regions with the lowest values & $\begin{array}{c}\text { By how many } \\
\text { times }\end{array}$ \\
\hline Central Federal District & Moscow & Ivanovo Oblast & 2.2 \\
\hline Northwestern Federal District & Nenets Autonomous Okrug & Pskov Oblast & 6.16 \\
\hline Southern Federal District & Volgograd Oblast & The Republic of Adygea & 1.6 \\
\hline North Caucasian Federal District & The Karachay-Cherkess Republic & The Chehen Republic & 1.8 \\
\hline Volga Federal Districr & Orenburg Oblast & Kirov Oblast & 2 \\
\hline Ural Federal District & Khanty-Mansi Autonomous Okrug & Kurgan Oblast & 4.7 \\
\hline Siberian Federal District & Altai Krai & The Republic of Buryatia & 2.8 \\
\hline Far Eastern Federal District & Sakhalin Oblast & Kamchatka Krai & 3.2 \\
\hline
\end{tabular}

The difference between the best (Nenets Autonomous Okrug - 61.6) and the worst (Chechen Republic - 5.2) indexes by the ratio of GRP per capita to the level of average monthly wages consists of almost 12 times. According to the data from 2012, the GRP of the Nenets Autonomous Okrug amounted to 3, 841,000 rubles, while the average monthly income among the region's population was 62,300 rubles. The same indexes for the Chechen Republic consisted of 79,000 rubles, and 15,300 rubles respectively. The difference between the GRP of the two regions amounts to almost 48 times, while the average monthly wages -4 times. By the way, the difference between the GRP of the Nenets Autonomous Okrug and Arkhangelsk Oblast, the merger of which has been in the works, but is yet to happen, amounts to approximately 15 times, while the average wages -2.5 times. According to the agreement between the Arkhangelsk Oblast and the Nenets Autonomous Okrug from June 5, 2014, all governing authority beginning on January 1, 2015 would be transferred over to the Nenets Autonomous Okrug. The agreement should remain active until December $31^{\text {st }}$ of 2021. According to the legislation, a merger between an okrug and another constituent of the Russian Federation
There are 22 regions with the ratio of the GRP per capita and the level of average monthly wages with the value of 15 or higher. None of such regions are within the North Caucasian or Southern federal districts. The analysis of the aspects of socio-economic development of the regions using the ratio of the GRP indexes and average monthly salaries of the population allowed us to highlight four types of regions depending on the nature of the correlation of the above indexes:

- Group A (the leading regions with the high level of GRP and average monthly wages);

- Group B (regions with the high level of GRP, but a low level of average monthly wages);

- Group C (regions with a lower level of GRP, but fairly high level of average monthly wages);

- Group D (regions with a low level of GRP and a low level of average monthly wages).

In 2012the GDP per capita of the population in Russia amounted to 434,481 rubles. Out of all regions, the GRP of only 11 of them has exceeded that number. The average monthly wages in 2012 amounted to 23,200 rubles, and there are 20 regions that have exceeded that value. Thus, the 
group A consists of 11 regions; no regions fit the group B; group $\mathrm{C}$ consists of 9 regions; the rest of the regions belong to group D (see Table 3). the imported manufacturing components, high and growing rates for power and other utilities. In addition to that, a significant problem that affects the industrial growth is the

Table 3

Grouping of the regions by the ratio of GRP per capita and the level of average monthly wages

\begin{tabular}{|c|l|}
\hline A & $\begin{array}{l}\text { Nenets Autonomous Okrug, Khanty-Mansi Autonomous Okrug, Yamalo-Nenets Autonomous Okrug, Sakhalin } \\
\text { Oblast, Tyumen Oblast without autonomous okrug, the Komi Republic, Chukotka Autonomous Okrug, Magadan } \\
\text { Oblast, Moscow, St. Petersburg }\end{array}$ \\
\hline B & No regions \\
\hline C & $\begin{array}{l}\text { Khabarovsk Krai, Kamchatka Oblast, Sverdlovsk Oblast, Mirmansk Oblast, Samara Oblast, Moscow Oblast, } \\
\text { Arkhangelsk Oblast wthout autonomous okrug, Tatarstan, Perm Krai }\end{array}$ \\
\hline D & The rest of the regions \\
\hline
\end{tabular}

The group A consists mostly of the resource regions and the cities of the federal constituency, i.e. the regions that represent the long-standing models of utilization of natural and administrative resources. The middle group $\mathrm{C}$ represents a model where the indexes of the GRP per capita are lower, while the level of income is higher than the national average. It is a fairly small group consisting of 9 regions with the developed manufacturing or processing industries, which also hold the positions of the key transportation hubs. Thus, within the GRP structure of the Sverdlovsk Oblast and Perm Krai the biggest portion belongs to the manufacturing industry $27.1 \%$ and $31.4 \%$ respectively; in Tatarstan and Samara Oblast - mineral extraction (21.3\% and $14.7 \%$ ); in Khabarovsk Krai - transportation and communication (18.7\%).

The specificity of the group D consists in the fact that within the GRP structure of the regions of this group the main portion is attributable not to manufacturing, but such industries as wholesale and retail, construction and government administration, military and defense, and social insurance. As can be seen from the data of the Federal State Statistics Service, in the Chechen Republic for example, in 2012 the biggest part of the GRP belonged to government administration, military and defense, and social insurance $-20.9 \%$ (while the national average is only $4.6 \%$, which is 5 times lower than in the Chechen Republic). In Dagestan the largest portion within the structure of GRP was in the wholesale and retail $-25.7 \%$; in Ingushetia-government administration, military and defense, and social insurance $-28.5 \%$.

Within the old industrial oblasts of the Central Russia, within Ivanovo Oblast for example, the greatest portion within the structure of GRP belonged to the manufacturing industry $-19.6 \%$. However, the local industry has been suffering from the lack of investments into upgrades of equipment and technologies for many years. The situation is further aggravated by the high import fees and the taxation if human resource deficit and the insufficient qualification level of personnel of all levels, which is the result of low wages [5]. Similar problems are inherent for most of the old industrial oblast of Central Russia and Volga region, and with the crisis of 2014-2015 the situation only worsened:

- Insufficient volume of orders for manufacturing of products in the light industry, machinery, as well as production instability of many enterprises;

- Low coefficient of capital replenishment;

- Low levels of industrial capacity utilization in many enterprises;

- Low profitability of the manufactured products;

- Mono-structuredness of the economy of the regions.

Even within the traditional agricultural regions, the biggest part of the GRP belongs not to agriculture, but to wholesale and retail sales. For example, within the GRP structure of the Republic of Adygea it consists of 23.1\%; in Stavropol Krai - 21.1\%; Rostov Oblast - 19.5\%.

However, the group D is very diverse in its composition, which we do not see in the ratio of the level of GRP and the level of average monthly wages of the population. Thus in absolute values the lowest level of GRP per capita in 2012 is recorded in the Chechen Republic - 78,934 rubles, while the average monthly salary across the republic was 15,274 rubles. At the same time, the lowest monthly wages are recorded in Kalmykia - 10,190 rubles, while the level of GDP per capita consisted of 119,183 rubles. A similar situation has formed in the Kabardino-Balkar and Karachay-Cherkess republics, and the Tyva Republic. As we have already noted, in the Chechen Republic in 2012 the largest portion within the structure of the GRP belonged to the government administration, military and defense, and social insurance - 20.9\%. In Kalmykia, Kabardino-Balkaria, KarachayCherkessia, and Tyva the biggest portion belonged to the agriculture, hunting, and forestry $-34.2 \%, 17.4 \%, 18.5 \%$, 
DOI: $10.7256 / 1811-9018.2015 .10 .15672$

При цитировании этой статьи сноска на доі обязательна

\section{Право и политика 10 (190) • 2015}

and $13.8 \%$ respectively.

Evidently, the socio-economic situation of the regions depends upon a whole complex of factors, which must be considered in forming a strategy for their development.

The "GRP per capita" index is the basic index for comparison and classification of the economies, including on a global scale. Thus, the methodology of the World Economic Forum allows us to use this index to classify the regions into three groups by quality of development: developing by means of industrial factors; developing by means of efficiency of resource usage; developing by means of innovation (see Table 4). to become the most dynamic region in Russia by tempo of economic growth, which will allow it to enter the ranks of 30 leading regions in Russia by GRP per capita and advance to the innovational type of development [6].

Unfortunately, despite the rather optimistic goals laid into foundations of the regional strategies for socioeconomic development, the current federal policy with regards to regions is mostly aimed not at innovational development, but at resolving other issues. As noted by experts, the current federal regional policy reflects the geopolitical priorities of the Russian authorities: support of the distant Far East that borders with China, the turbulent

Table 4

\section{Basic characteristics of the stages of economic development of the regions}

\begin{tabular}{|c|c|c|c|}
\hline \multirow[b]{2}{*}{ Characteristics } & \multicolumn{3}{|c|}{ Stages of economic development } \\
\hline & $\begin{array}{c}\text { Economy developing by means } \\
\text { of factors }\end{array}$ & $\begin{array}{c}\text { Economy developing by } \\
\text { means of efficiency }\end{array}$ & $\begin{array}{c}\text { Economy developing } \\
\text { by means of } \\
\text { innovation }\end{array}$ \\
\hline GRP per capita & $<\$ 2,000$ & $\$ 3,000-\$ 8,999$ & $>\$ 17,000$ \\
\hline $\begin{array}{l}\text { Mechanism of economic } \\
\text { development }\end{array}$ & $\begin{array}{l}\text { Extensive development based } \\
\text { on exploitation of natural } \\
\text { resources and cheap low-skilled } \\
\text { labor. Low level of productivity, } \\
\text { wages, and quality of life. }\end{array}$ & $\begin{array}{l}\text { Intensive development } \\
\text { based on improvements to } \\
\text { the efficiency of economic } \\
\text { activity and growth in } \\
\text { investments. Increase of } \\
\text { the levels of productivity, } \\
\text { wages, and quality of life. }\end{array}$ & $\begin{array}{l}\text { Intensive } \\
\text { development based } \\
\text { on innovation and } \\
\text { high-tech products. } \\
\text { High level of wages } \\
\text { and quality of life as } \\
\text { a necessary condition } \\
\text { for quality production } \\
\text { and competitiveness. }\end{array}$ \\
\hline Key factors for competitiveness & $\begin{array}{l}\text { Institutes } \\
\text { Infrastructure } \\
\text { Macroeconomic environment } \\
\text { Health and basic education. }\end{array}$ & $\begin{array}{l}\text { Higher education } \\
\text { Efficiency of goods market } \\
\text { Efficiency of job market } \\
\text { Development of financial } \\
\text { market } \\
\text { Technological capabilities } \\
\text { Volume of the market. }\end{array}$ & $\begin{array}{l}\text { Level of business } \\
\text { development } \\
\text { Innovations. }\end{array}$ \\
\hline
\end{tabular}

Source: The Global Competitiveness Report. 2014-2015. Geneva: World Economic Forum, 2014. P. 9-10.

While overall throughout Russia we can speak of the second stage of economic development - the economy driven by the efficiency factors, with regards to many separate regions, we are talking about economy that is driven by the basic factors: institutes, infrastructure, and condition of the macroeconomic environment. Therefore, the strategic planning for the socio-economic development, which is currently being developed and is beginning to be implemented on all levels, is another sign by which we can assess the position and prospects of the regions. So the key strategic goal for the Chechen Republic for the 2012-2025 is
North Caucasus, and the annexed Crimea [7]. Since end of March to December of 2014 Crimea has received 125 billion rubles from federal budget $(7.2 \%$ of the entire federal subsidy for the regions). The sizeable stimulus could not be fully appropriated and the budget showed surplus of $13.4 \%$. The transfer payments for the Far East have decreased to 210 billion rubles in 2014 (from 243 billion rubles in 2013), all republic of the North Caucasus received 189 billion rubles (in 2013 it was 182 billion rubles). If the transfer payment is broken down, Crimea received twice as much per person than all republics of the North 
Caucasus. The level of subsidization in Crimea $(80 \%)$ can only be compared to Ingushetia $(87 \%)$ and Chechnya $(82 \%)$, and taking into account that Crimea retains all of the VAT, which by law should be transferred to the federal budget, its subsidization reaches $85 \%$. Subsidization of Sevastopol is somewhat lower (70\%) and is comparable with Dagestan. The prioritized support of Crimea comes from other Russian territories, which worsens the state of their budgets in this crisis period.

Therefore, the balancing of Russian regions by socioeconomic level still remains a distant prospect. At this time the government conducts a fairly controversial policy. On one hand, it does everything possible to stimulate the development of innovational economy, but on the other, it uses predominantly administrative methods, which is especially noticeable in the regional perspective. Innovational territory is not an administrative territory, but a cluster, since innovational center pulls human resources not by the administrative sign, but by market [8]. For the territorial communities that are oriented towards innovational progress the most important part is the local cultural, economic, and social potential for development. Nevertheless, the weakness and inefficiency of the institutional environment still remains the "Achilles heel" of the Russian economy, which is also negatively affected by the spread of corruption, favoritism, and distrust towards law [9].

Inclusion of the indexes of the level of average monthly wages and the level of GRP into the long-term strategies of socio-economic development of the regions must be based not only on administrative measures, but also development of inner potential of the regions, consideration of their cultural, economic, and social specificities.

\section{Библиография:}

1. Голяшев А.В., Григорьев Л.М. Типы российских регионов: устойчивость и сдвиги в 2003-2013 годах. Аналитический доклад. М.: Аналитический центр при Правительстве Российской Федерации, 2014.

2. Гореева Н.М., Демидова Л.Н., Черняев С.И. Анализ факторов, формирующих взаимосвязи роста валового регионального продукта и уровня жизни населения в Калужской области // Современные проблемы науки и образования. 2013 . № 2.

3. Зубаревич Н. Мониторинг кризиса и посткризисного развития регионов России http://www.socpol.ru/atlas/overviews/ social_sphere/kris.shtml\#no31

4. Кошевой О.С., Фролов С.Г. Определение рационального сочетания доли среднедушевых доходов населения в составе валового регионального продукта // Известия высших учебных заведений. Поволжский регион. Общественные науки. 2013. №1(25). C.97-103.

5. О стратегии социально-экономического развития Ивановской области до 2020 года. Закон Ивановской области от 11 марта 2010 г. № 22-О3.

6. Стратегия социально-экономического развития Чеченской Республики до 2025 г. http://www.investchechnya.ru/upload/ docs/strategija-socialno-yekonomicheskogo-raz5368d0aee72b61399378094.pdf

7. Человеческий потенциал для инновационной экономики / Под. ред. д.э.н. Иванова С.А. ИПРЭ РАН. СПб.: ГУАП, 2011.

8. The Global Competitiveness Report. 2014-2015. Geneva: World Economic Forum, 2014.

9. Морошкина М.В. Исследование различий развития российских регионов на основе динамики и уровня валового регионального продукта // Теоретическая и прикладная экономика. - 2013. - 1. - C. 64-90. DOI: 10.7256/2409-8647.2013.1.822. URL: http://www.e-notabene.ru/etc/article_822.html

10. Ю. Б. Миндлин, Ю. Н. Шедько Стратегии инновационного развития экономики региона // Национальная безопасность / nota bene. $-2011 .-5 .-$ C. $77-87$

\section{References (transliterated):}

1. Golyashev A.V., Grigor'ev L.M. Tipy rossiiskikh regionov: ustoichivost' i sdvigi v 2003-2013 godakh. Analiticheskii doklad. M.: Analiticheskii tsentr pri Pravitel'stve Rossiiskoi Federatsii, 2014.

2. Goreeva N.M., Demidova L.N., Chernyaev S.I. Analiz faktorov, formiruyushchikh vzaimosvyazi rosta valovogo regional'nogo produkta i urovnya zhizni naseleniya v Kaluzhskoi oblasti // Sovremennye problemy nauki i obrazovaniya. 2013 . № 2.

3. Zubarevich N. Monitoring krizisa i postkrizisnogo razvitiya regionov Rossii http://www.socpol.ru/atlas/overviews/social_sphere/ kris.shtml\#no31

4. Koshevoi O.S., Frolov S.G. Opredelenie ratsional'nogo sochetaniya doli srednedushevykh dokhodov naseleniya v sostave valovogo regional'nogo produkta // Izvestiya vysshikh uchebnykh zavedenii. Povolzhskii region. Obshchestvennye nauki. 2013. №1(25). S.97-103.

5. Moroshkina M.V. Issledovanie razlichii razvitiya rossiiskikh regionov na osnove dinamiki i urovnya valovogo regional'nogo produkta // Teoreticheskaya i prikladnaya ekonomika. - 2013. - 1. - C. 64-90. DOI: 10.7256/2409-8647.2013.1.822. URL: http:// www.e-notabene.ru/etc/article_822.html

6. Yu. B. Mindlin, Yu. N. Shed'ko Strategii innovatsionnogo razvitiya ekonomiki regiona // Natsional'naya bezopasnost' / nota bene. $-2011 .-5 .-$ C. $77-87$ 